\title{
'IT IS IMPORTANT ARTISTS REACT TO THE WORLD IN WHICH WE ALL LIVE': AN INTERVIEW WITH PHILIPPE MANOURY ON LAB.ORATORIUM
}

\author{
Luis Velasco-Pufleau and Philippe Manoury
}

\begin{abstract}
Lab.Oratorium (2019) is the concluding part of Philippe Manoury's Köln Trilogy. It follows In situ (2013) and Ring (2016) in exploring the spoken voice as a musical element, the wider possibilities of the orchestra, and the use of sound spatialization and live electronics. Lab.Oratorium is also a work deeply rooted in the present. In this interview, Philippe Manoury discusses the political and poetic significance of this work, conceived as an artistic response to Europe's responsibility in the tragic situation of migrants around the Mediterranean. He also develops his thoughts on musical form, spatialization and creative process in music.
\end{abstract}

Luis Velasco-Pufleau: Lab.Oratorium was premiered in May and June 2019 at the Philharmonies of Cologne, Hamburg and Paris. What is the subject you explored in this work?

Philippe Manoury: The main subject of Lab.Oratorium is related to the current tragic situation of migrants around the Mediterranean. My goal is to make as many people as possible aware of the condition of these human beings who are not being treated as such. I am not relying on strategic and international issues in this matter - there is no reason for them to be in an artistic work - but on the fact that we are letting our fellow human beings perish when it is possible to avoid it.

LVP: Your work was inspired by and paid tribute to the work carried out by the crew of the Aquarius, the boat of Médecins Sans Frontières and SOS Méditerranée that, after rescuing more than thirty thousand people between 2016 and 2018, was forced to stop its rescue operations in December 2018.

PhM: Yes, initially we wanted to involve the crew of the Aquarius in Lab.Oratorium. We had imagined having rescuers testify, as a kind of report in the middle of the work. In the end, we gave up on this idea for two reasons. The first is that if we bring in sailors, why not bring in migrants too and also what right do we have to speak for them? We should not try to give ourselves a clear conscience: we make a work of art about misery and people applaud us! We had to be careful about 
the images that we could convey so that the migrants and refugees are not misrepresented. The second reason we gave up on the idea was that in the structure of the work, which is about 90 minutes long, we could have integrated the Aquarius rescuers for only about ten minutes, and that would have been really too short to express the magnitude of the task they had to accomplish. However, we organised public meetings after the concerts with people from the Aquarius. This allowed those of the public who wished to do so to talk to the people who participated in the creation of Lab.Oratorium: Nicolas Stemann, François-Xavier Roth, the actors, singers and people from the Aquarius.

LVP: The European Union has adopted migration and asylum policies that have been strongly criticised by a large number of citizens and non-governmental organisations (NGOs), such as the agreements signed with Turkey in March 2016 that impose the management of refugees outside its borders in return for the payment of considerable sums of money.

PhM: The European Union should take a responsible attitude towards these populations because it bears an obvious responsibility in this disgraceful situation. We can look back to the colonies that European countries created over centuries. The chaos in which these populations find themselves now is largely the legacy of Europe's colonial policies. While feeling very European and also very Europhile, I am aware that - instead of exercising its duty of hospitality - Europe is trying to get off the hook, cover itself and shirk its responsibilities. I regret this as a European and as a human being. This is an unacceptable situation.

LVP: This irresponsible attitude of Europe is not an isolated phenomenon.

PhM: The second message I would like to convey concerns the danger of the rise of nationalism and populism, which seems to be deadly. The current humanitarian tragedy exacerbates the nationalist and populist reactions not only in European countries but also in the United States and South America. This phenomenon goes against the foundations of civilisations, namely the free movement of populations and the sharing of cultures and knowledge that they bring with them.

LVP: Lab.Oratorium is in a way a response to these phenomena. Do you consider your work as a political work?

PhM: If it is political, it is certainly not in the sense of committing to a party or ideological activism; rather it would be in a philosophical sense. It talks about poor management of human affairs. I would like it to raise people's consciousness. However, I do not see myself as a 'committed' composer, such as Luigi Nono in the 1950s and 1960s.

LVP: What does it mean for you to raise consciousness? Is it making people who listen to your music think about things that most of the time go unnoticed, making audible what is not, giving a voice to people who don't have it?

PhM: It is also a desire to anchor my creation in what is happening in our time. I think it is important artists react to the world in which we all live, but neither should that be made an obligation. An increasingly insistent trend - it is almost becoming a diktat - is for works of art to be absolutely social markers. I think you are missing art if you demand that from works; you are losing an essential dimension of 
it. For me it is a question of making clear that what is happening at the moment is a brake on civilization, on art, in short on everything that makes us human.

\section{Poetry and non-conventional narrative forms}

LVP: Is your objective of raising consciousness achieved through a narrative structure?

PhM: Lab.Oratorium deals less with a story than a situation. I am very attached to unconventional narrative forms, such as those found in Fellini's or Bergman's films, or in Beckett's theatre. For me the emotion is stronger in this kind of situation than in a story with very classically constructed characters. There are more symbolic spaces into which the audience can enter, communication seems more direct to me.

LVP: How did you articulate it in the work?

PhM: Lab.Oratorium is based on a rigorous form divided into ten sections (see Example 1). This form was necessary for practical reasons. I had decided to use two choirs, including a large amateur choir. So first I had to finish composing the parts where the choirs are involved, in order to give the amateur choir time to get familiar with the scores. In short, I composed Lab.Oratorium like a jigsaw made up of different parts, but organised according to a very precise formal structure.

LVP: Is this formal structure related to the situation of migrants around the Mediterranean?

PhM: Yes, the idea is that the Philharmonie stage represents a boat on which the orchestra, the actors and the audience are seated, as if it were a cruise ship on which rich people travel for pleasure and others travel in order to flee a terrible situation. After the prologue there is an orchestra piece that represents the boat trip. Then, suddenly, the members of the chamber choir are heard from the auditorium, where they have entered unnoticed with the audience. They symbolise a first wave of migrants who were hidden in the boat and who now get out to express what they have experienced. Later, when the boat docks, there is the large amateur choir of about 70 people who invade the whole venue. I deliberately play on this idea, terrifying for some, of migrants who come to 'invade us', in order to arouse fear on the one hand and on the other, to show that these 'invaders' can be people of culture who express themselves in poetry - in this case the wonderful poetry of Ingeborg Bachmann (1926-1973).

LVP: What is the destination of this cruise ship full of migrants?

PhM: The boat arrives somewhere, it could be Marseille, Malta, Naples, wherever. Once they arrive the choirs disperse. This dispersion is followed by two passages: one that relates the journey of these people through cities and countries, and the other that is the period of the dream. This period represents one of the characteristic phenomena of this type of migration, that it carries a great fatigue: the lives of these people are both distressing and very tiring. I imagine that, during these gruelling experiences, these people must be dreaming a lot. So there is a dreamlike passage, which leads to a grand finale in which everyone participates, until the two choirs disappear in the venue.

LVP: What texts do you use in Lab.Oratorium and how do you mobilise them in the narrative? 


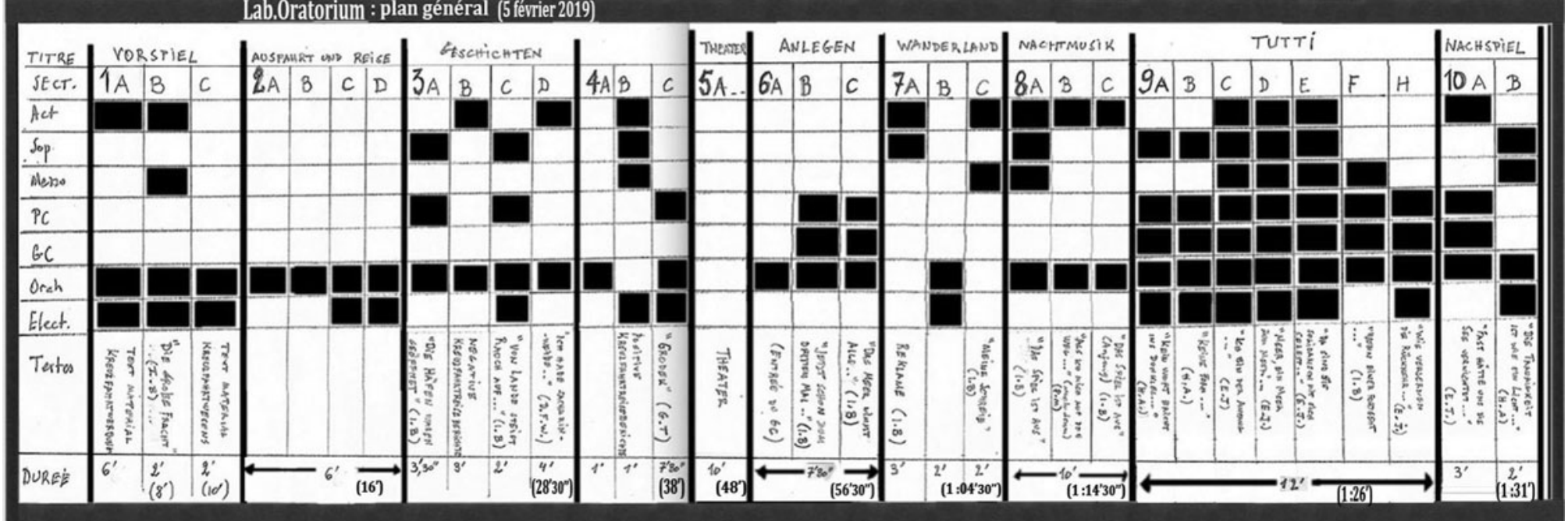

Example 1: Lab.Oratorium's formal structure (draft, 5 February 2019). 
PhM: The thread running through my work is made up of poems by Ingeborg Bachmann. I chose several of them on the idea of travel and uprooting. She was a poet of the post-World War II generation who wrote extraordinarily strong work. Then there is the last poem of Georg Trakl (1887-1914), 'Grodek', written at the beginning of the First World War. I had already set to music this poem that expresses the horror of war. The link with the subject of Lab.Oratorium is precisely the fact that war is the reason why these people flee; there are not only economic reasons, it is principally war. There are also fragments by the Austrian author Elfriede Jelinek (born 1946) from her play 'Die Schutzbefohlene' (The Protected). The actors invest in these texts since there is a part of the work that was finished during the rehearsals. This is one of the specificities of Lab.Oratorium: it is a work in progress. I wrote the text of the dream myself and of course Nicolas Stemann is also involved in its writing. Finally, the very end of the piece consists of a melody for both voices and orchestra on a poem that Hannah Arendt wrote in exile in the United States and which ends with the following verse: 'Lucky is he who has no home; he still sees it in his dreams' (Wohl dem, der keine Heimat hat; er sieht sie noch im Traum). I connected this poem with one by Nietzsche. Actually, the very young Nietzsche had to renounce his Prussian citizenship and to become stateless in order to be accepted in Switzerland as a professor of philology at the University of Basel. Later he developed a vast dialectical reflexion on the topic of being European and stateless in the text Wir Heimatlosen (We, without homeland) of the fifth book of his The Gay Science and, in the same period, in 1884, he wrote a poem (Der Freigeist, which he renamed as Vereimsamt, Lonesome), in which the last verse says 'Woe betide is he who has no home!' (Weh dem, der keine Heimat hat!).

\section{Music notation and creative process}

LVP: How did you pursue your reflection on notation and creative process in Lab.Oratorium?

PhM: There are passages that are not notated, situations that were created on the spot during rehearsals. That is why the work is called Lab. Oratorium; it is a laboratory where we have developed things in situ the title evokes more the genre than the subject of the work itself. For example, in the middle of the work, there is a passage that is pure theatre, where I create electronic music live. There are other times when Nicolas Stemann had to develop a dramaturgy on texts chosen during rehearsals. At the end of the work, when the choirs leave the stage, there is a theatrical situation, a dialogue between the two actors in the form of an argument. One of the actors represents a person who does not want migrants and the other a person who tries to convince them that it is their duty to welcome them. There are also all the live computer procedures for electronic music. It is important to understand that musicians and singers perform predetermined scores in broad terms, while computers react according to very different procedures. They constantly calculate music that did not exist before in any form. Music is being composed in the moment the audience hears it; and despite this fundamental difference, these two forms of music must speak with the same voice. I'm always seeking coherence, never simply collage.

LVP: In your summary of the lectures of the annual Chair in Artistic Creation at the Collège de France, which you held in 2017, you wrote: 
'The history of Western music is made by composers who have constantly redefined the very nature of what is called "music"'. In what way is Lab.Oratorium a step on your path as a composer?

PhM: The question I asked myself during these lectures was about what I called the limits of music: where does music start and where does it stop? A constant in the history of music is that composers have always tried to push the boundaries of how music is defined. One of the things I looked at in Lab.Oratorium and had some experience with in Kein Licht (2017), is the use of the spoken voice as a musical element. We worked at IRCAM on ways to transform the spoken voice of actors into a recitative. We keep the vocal inflections, the prosody, the rhythmisation, while supporting the sound side by extending the sounds and transposing them onto real notes. The voices thus tend towards a kind of new recitative, an ambiguous sound form, between the spoken and the sung.

What is interesting for me today is the way music is evolving, although we are no longer in a linear vision of 'progress'. I am currently thinking about what is called 'flocking behaviour', which I hadn't thought about at the time of the lectures at the Collège de France. An obvious example is birds who, when they fly in groups, create shapes that are always evolving but always in perfect cohesion. It seems as if all this were organised. What is fascinating about this phenomenon is that there is no 'leader'. One bird, for one reason or another, decides to go in a certain direction and leads the whole group in that direction. Then another one will do the same and so on. But this is not subjected to the power of a leader or queen, as it is the case with bees, for example. I think music evolves in the same way. You have a Debussy who found new harmonies and forms and thus diverted a whole musical thought, then you have a Schoenberg, a Stravinsky, a Stockhausen, who went in other directions and brought in their respective wake a whole multitude of composers. The influence of these individuals is immense, their legacy being still perceptible today.

\section{Spatialization of sound and orchestra}

LVP: How did you continue your experimentation on the spatialization of sound in Lab.Oratorium?

PhM: In the other two works of the Köln Trilogy, I tried to expand possibilities of the orchestra by spatializing it around the audience. Since the Mannheim School and Haydn we have had the same orchestra structure. It is just bigger now, but it still has the same overall architecture and layout. I cannot imagine that we could be satisfied with this structure indefinitely. So what interested me was to change the place of the orchestra's instruments and to change the whole situation of the orchestra. I couldn't do it in Lab.Oratorium at the same level as in In situ and in Ring because there is already the spatialization of the choirs, but there is also the architecture of the three venues, the Philharmonies of Cologne, Hamburg and Paris. If I had decided to spatialize the orchestra in a specific way, it would have been possible in Cologne but not in Paris. So I got around this problem by reducing the orchestra a little and placing two groups of brass and percussion in the venue. The choirs move through the space in a different way in each venue. However, what I lost in real spatialization, I catch up through live electronics, which did not exist in the other two purely acoustic works. In electronic music I use synthetic sounds, string 
tremolos and artificial brass orchestras, which come to the left and right, where there are no musicians, in order to create the impression that the audience is in the middle of the sound. Live electronics make up for the musicians' lack of real spatialization.

LVP: Have you conceived this spatialization of sound more as points in space or as moving lines?

PhM: There are both these ideas. There are layers of random sounds whose procedures were developed by Miller Puckette - that are very present and sweep the sound space. There is the circularity of sound, for example in a passage in which real brass interact with virtual brass - very high-quality sound synthesis created using Eric Lindemann's Synful program. In the same way, there is a section of the orchestra that plays a string tremolo on stage and the same tremolo is rotating around the audience, so that we no longer know if the sounds we hear come from the orchestra or elsewhere. There are also sound points in the venue space. For example, at the beginning of the adagio, which is supposed to be the night passage, I put sound points that light up, as if they were stars in the sky.

\section{Form and treatment of sound: giving meaning to sound}

LVP: In your inaugural lecture of the annual seminar at the Collège de France, you asserted that 'composing is about giving meaning to sound'. How can this idea help us to listen to Lab.Oratorium?

PhM: When I say 'meaning', I mean the musical meaning and not the semantic meaning. There is music that makes no sense to me; it's when I find myself in a situation where I can't anticipate anything. I listen to what comes to me and think that something else could very well have happened. If I can anticipate even a tenth of what is really happening, I can say that there is a musical meaning. When you have sound material, the essential part of the composition is to try to develop a musical sense, that is, to give it as a recounted sound narrative. Even if it's not a concrete narrative - music is always somehow abstract - I think we can talk about the musical meaning. In Lab.Oratorium I cannot define precisely this meaning, no more than in another work. Giving meaning to sound structures means creating the desire and the possibility of anticipating. You can compare it with the spoken language in which, if you are continually disorientated and surprised, you lose meaning. Even if in music it is not a semantic meaning that matters, the process of anticipation is just as fundamental.

LVP: This musical meaning is more like coherence in the organization of sound material that passes through the form and treatment of sound.

PhM: I attach great importance to the form. For me it is something that is even more important than sound. I think form is what keeps the listener on the edge of their seat during the musical time. If the form is not well conceived, there will be holes or gaps in the understanding. What is interesting about a work that unfolds over time whether it is musical, cinematographic or theatrical - is that the time during which it speaks to you is really full. I pay great attention to form, proportions, contrasts, silences. I make sure that it is not a basic form but, on the contrary, quite complex. A form that is too simple is immediately perceived: the form is not there to be perceived as 
such but to carry musical expression. I think that a rich form is not perceived as a form. However, when there is a lack of thought about form, then its absence literally jumps out at you.

This is an edited translation of an interview conducted on 7 February 2019 by video call between Strasbourg (France) and Fribourg (Switzerland). An excerpt from the interview was published in French: Luis Velasco-Pufleau, 'Lab.Oratorium et l'Europe : Entretien avec Philippe Manoury', L'Étincelle : journal de la création à l'Ircam, 19 (2019), pp. 10-11. This publication is part of the project 'Political Ontologies of Music' (CRSK-1_190433), funded by the Swiss National Science Foundation (SNSF).

Lab.Oratorium was a co-production by Gürzenich-Orchester Köln, Ircam-Centre Pompidou, Philharmonie de Paris and Elbphilharmonie Hamburg. The first performances were given on 19, 20 and 21 May 2019 at Kölner Philharmonie, 27 May 2019 at Elbphilharmonie Hamburg, and 3 June 2019 at Philharmonie de Paris.

Rinnat Moriah, soprano

Tora Augestad, mezzo-soprano

Patrycia Ziolkowska, actress

Sebastian Rudolph, actor

Lab.Chor (Köln)

Chor zur Welt (Hamburg)

Stella Maris (Paris)

SWR Vokalensemble

Gürzenich-Orchester Köln

François-Xavier Roth, conductor

Nicolas Stemann, stage director

Thomas Goepfer, computer musical designer (IRCAM)

Julien Aléonard, sound engineer

Philippe Manoury, composer and live electronics 